\title{
Zgoda domniemana a cele transplantacji
}

\author{
Piotr Ochotny \\ Wydział Filozofii Chrześcijańskiej \\ Uniwersytet Kardynała Stefana Wyszyńskiego \\ ul. Wóycickiego 1/3, 01-938 Warszawa, pochotny@poczta.onet.pl
}

\begin{abstract}
Streszczenie
Autor w swoim artykule zwraca uwagę na problem zgody domniemanej, i szerzej prawo do samostanowienia sięgającego poza granice życia człowieka, w kontekście celów transplantacji. Podstawowy akt prawny zawierający uregulowania dotyczące transplantacji, a mianowicie Ustawa z dnia 01.05.2005 r. o pobieraniu, przechowywaniu i przeszczepianiu komórek, tkanek i narządów (Dz. U. z 2005 r. Nr 169, p0z. 1411), wylicza cztery cele, dla których mogą być pobierane komórki, tkanki i narządy ze zwłok ludzkich: diagnostyczny, terapeutyczny, naukowy i dydaktyczny. Zgodnie z art. 5 ust. 1 „pobrania komórek, tkanek lub narządów ze zwłok ludzkich w celu ich przeszczepienia można dokonać, jeżeli osoba zmarła nie wyraziła za życia sprzeciwu". Zapis ten jest przykładem tzw. zgody domniemanej, na podstawie której przyjmuje się, iż dany człowiek za życia wyraził się aprobująco o możliwości ofiarowania swoich organów, a więc faktycznie nie złożył odpowiedniego sprzeciwu, podważającego domniemanie zgody. Sformułowanie „w celu ich przeszczepienia" wyraźnie wskazuje, że instytucja sprzeciwu ma zastosowanie jedynie w przypadku pobierania tkanek, komórek i narządów w celach leczniczych. Dawca nie ma jednak prawa do wyrażania ewentualnego sprzeciwu wobec pozostałych celów: diagnostycznego, naukowego i dydaktycznego. W celu rozwiązania swoistego impasu prawnego proponuje się rozszerzenie zakresu zgody domniemanej.
\end{abstract}

\section{Słowa klucze}

zgoda domniemana, cele transplantacji, transplantologia, prawo do samostanowienia, sprzeciw

\section{Wstęp}

Transplantacja jest jedną z najbardziej kontrowersyjnych ingerencji medycznych. Z jednej strony stanowi realną, skuteczną, często jedyną drogą ratowania, przedłużania lub ułatwiania życia ludzkiego, będącego jedną z najważniejszych wartości. Z drugiej natomiast wiąże się z koniecznością pobierania i przeszczepiania komórek, tkanek i narządów. Niezależnie od kontrowersji, jakie wzbudza, zabieg ten już od ponad pięćdziesięciu lat ratuje życie pacjentom ze schyłkową niewydolnością wielu narządów, ofiarom wypadków, a transplantologia jako dziedzina medycyny uległa ogromnemu rozwojowi, co skutkuje dziś zarówno podniesieniem skuteczności tej metody terapeutycznej, jak i znacznym rozszerzeniem wskazań do jej zastosowania. Celem artykułu jest przedstawienie problemu zgody domniemanej i szerzej prawa do samostanowienia ${ }^{1}$ sięgającego poza granice życia człowieka, w kontekście celów transplantacji.

1 Najczęściej o samostanowieniu mówi się w kontekście prawa międzynarodowego jako pra- 


\section{Pojęcie transplantacji}

Słowo „transplantacja” pochodzi od łacińskiego czasownika transplantare, który oznacza czynność polegającą na przeszczepieniu lub przesadzeniu. Termin ten powstał ze złożenia dwóch łacińskich słów: trans oznaczającego „za, poza, z tamtej strony” oraz plantatio oznaczające sadzenie roślin (Kowalewska et al. 2013: 133), i odnosi się do metody chirurgicznego przeszczepiania komórek (np. szpiku), tkanek (np. skóry) i narządów (np. serca) w obrębie jednego organizmu lub między dwoma organizmami. Przeszczepiany fragment nazywa się transplantem lub przeszczepem (Ptaszek et al. 2016: 102). Transplantacja polega więc na leczeniu przy pomocy wymiany organów, tkanek bądź substancji (Wolf et al. 1993). Natomiast według Małej encyklopedii medycyny transplantacja to „wyrównywanie ubytku $\mathrm{w}$ ustroju, przez operacyjne przeniesienie tkanek lub narządów" (Bogusławski 1987). $\mathrm{Z}$ kolei precyzyjną definicję transplantatu podaje Stownik encyklopedyczny R. M. Youngsona. Według niego transplant to „tkanka lub narząd pobrany z innej okolicy ciała lub innej osoby (dawcy), wszczepiony operacyjnie w celu wypełnienia ubytku lub zastąpienia niewłaściwie funkcjonującej tkanki czy narządu" (Youngson 1997: 404).

wa narodów do samookreślenia statusu politycznego, społecznego, gospodarczego i kulturalnego oraz prawa do utworzenia własnego państwa lub połączenia się z państwem już istniejącym. Samostanowienie w wymiarze jednostkowym (indywidualnym) rozumiem jako moment autodeterminacji, będącej aktem decyzji człowieka, która konstytuuje jego wolność. Owo samostanowienie dokonane w akcie decyzji jest uwarunkowane zarówno procesem poznawczym, w którym interioryzując poznawczo rzeczy i treści dobra doświadczam, że posiadam w sobie samego siebie (samoposiadanie), a następnie doświadczam, że poprzez mą wolę panuję nad swymi aktami chcenia i nie chcenia, a więc doświadczam samopanowania. W akcie decyzji człowiek konstytuuje siebie przyczyną sprawczą i realnym źródłem działania. Samostanowienie wraz z podbudowującymi je strukturami samoposiadania i samopanowania jest istotą ludzkiej wolności (Krąpiec 1997: 29).
W znaczeniu medycznym zabieg transplantacji (przeszczepiania) oznacza operacyjne przeniesienie komórek, tkanek lub całych narządów (przeszczepów) w przypadku określonych stanów chorobowych, $\mathrm{z}$ jednego miejsca $\mathrm{w}$ drugie $\mathrm{u}$ tego samego człowieka lub od jednego człowieka (dawcy) do drugiego (biorcy), które ma na celu uzupełnienie ubytku lub przywrócenie czynności (Breczko 2014: 184; WiśniewskaŚliwińska 2014: 184). Ze względu na przedmiot transplantacji wyróżnia się przeszczepy organów, przeszczepy tkanek i przeszczepy komórek (Guzik-Makaruk 2008). Zgodnie z powyższym ujęciem transplantacja może dotyczyć przemieszczania narządu lub jego części w obrębie ciała jednej osoby lub z osobnika na osobnika w obrębie tego samego gatunku, czy nawet pomiędzy różnymi gatunkami (Wałaszewski, Stryjenka-Rowińska 2004: 35-38; 48-49). Biorąc pod uwagę odmienność genetyczną dawcy i biorcy rozróżnia się cztery podstawowe rodzaje transplantacji:

- autogeniczne (autologiczne, własnopochodne, autografty) - polegają na przeniesieniu własnej tkanki lub narządu biorcy z jednego miejsca na drugie (np. przeszczepienie skóry, przeszczepienie żyły do układu tętniczego, przeszczepienie nerki z miejsca prawidłowego w inne) (Gomułka, Rewerski 2000: 1568).

- izogeniczne (syngeniczne, izologiczne) - oznaczają przeniesienie tkanki lub narządu między osobnikami identycznymi genetycznie. W warunkach naturalnych sytuacja taka istnieje tylko w przypadku bliźniąt jednojajowych, a przeszczep przyjmowany jest przez biorcę jak tkanki własne (Szmidt 2003: 396).

- $\quad$ allogeniczne (homogeniczne, bliźniopochodne, allografty, homotransplantacje) - oznaczają przeniesienie tkanki lub narządu między osobnikami różnymi genetycznie, jednak w obrębie tego samego gatunku, a więc 
z człowieka na człowieka, z myszy na mysz itp. (Szmidt 2003: 396).

- ksenogeniczne (heterologiczne, obcogatunkowe, odzwierzęce, ksenografty) polegają na przeszczepieniu tkanki lub narządu między osobnikami dwóch różnych gatunków (Duda 2011: 20).

\section{Transplantacja w prawie polskim}

Transplantacja regulowana jest w prawie polskim w podstawowym zakresie w ustawie z dnia 1 lipca 2005 roku o pobieraniu, przechowywaniu i przeszczepianiu komórek, tkanek i narządów ${ }^{2}$. Określa ona m.in. zasady przeszczepiania komórek (w tym komórek krwiotwórczych szpiku, krwi obwodowej oraz krwi pępowinowej), tkanek i narządów pochodzących od żywego dawcy lub ze zwłok ludzkich. W świetle omawianej ustawy transplantacja - co do zasady - jest dopuszczalną przez prawo interwencją medyczną, jednakże na zasadach w niej uregulowanych. Konieczność reglamentacji prawnej tej interwencji wynika z faktu, że tylko z punktu widzenia biorcy przeszczepu ma ona charakter terapeutyczny. Natomiast z perspektywy dawcy przeszczepu (żywego dawcy) interwencja ta przybiera już jednak postać nieterapeutyczną, a czasami wręcz obniża ogólny stan zdrowia i upośledza jego funkcje, okresowo lub na stałe (Żelichowski 2009: 145).

Ustawa transplantacyjna, stwarzając spójne i wyraźne ramy prawne transplantacji (podstawę legislacyjną), wprowadza słownik definicji legalnych (ustawowych) zawierających pojęcia ściśle powiązane z przeszczepami. Dawca według powyższej ustawy to żywy człowiek lub zwłoki ludzkie, od których pobiera się komórki, tkanki bądź narządy (A: art. 2, p. 2). Dawcą przeszczepu za życia może być każdy pełnoletni i nieubezwłasnowolniony człowiek (bez względu na płeć) (B: nr 79, poz. 556). Natomiast w przypadku dawców przeszczepu po śmierci

2 Zob. Dz. U. z 2005 r. Nr 169, poz. 1411. Poprzednio (tj. do dn. 1.01.2006 r.) problematykę tę regulowała ustawa z dnia 26 października 1995 r. o pobieraniu i przeszczepianiu komórek, tkanek i narządów (Dz.U. Nr 138, poz. 682 z późn. zm.). ustawa stanowi, że może nim być tylko człowiek, u którego stwierdzono śmierć mózgu „pobranie komórek, tkanek lub narządów do przeszczepienia jest dopuszczalne po stwierdzeniu trwałego i nieodwracalnego ustania czynności mózgu (śmierci mózgu)" (A: art. 9, p. 1). Dawstwo - co do zasady oznacza więc przekazywanie komórek, tkanek lub narządów ludzkich przeznaczonych do zastosowania u ludzi (A: art. 2, p. 3). Ustawa dopuszcza jednak przeszczepienie ludziom w celach leczniczych komórek, tkanek lub narządów pochodzących od zwierząt. Transplantacje ksenogeniczne (odzwierzęce) wymagają uzyskania pozytywnej opinii Krajowej Rady Transplantacyjnej i są regulowane są przepisami dotyczącymi eksperymentów medycznych zawartymi w ustawie o zawodach lekarza i lekarza dentysty (C: nr 226, poz. 1943).

Ustawa odrębnie reguluje pobieranie przeszczepów ze zwłok ludzkich i od żywych dawców. W obu przypadkach jednakowo rozumie pobieranie jako czynność, w wyniku której pozyskiwane są komórki, tkanki lub narządy (A: art. 2, p. 10). Komórka jest określona jako najmniejsza struktura morfologiczna i czynnościowa organizmu, która jest zdolna do podstawowych funkcji życiowych, występująca pojedynczo lub grupowo, niepowiązana ze sobą tkanką łączną (A: art. 2, p. 7). Z kolei tkanka to zespół komórek o wyspecjalizowanych funkcjach powiązanych ze sobą substancją międzykomórkową (A: art. 2, p. 10). Narząd według ustawy transplantacyjnej to „wyodrębniona i istotna część ludzkiego ciała, zbudowana z różnych tkanek, zdolna do utrzymywania swojej struktury, ukrwienia i możliwości pełnienia autonomicznych funkcji fizjologicznych" (A: art. 2, p. 9). Pojęciem ściśle powiązanym z transplantacją jest bank tkanek i komórek. Stanowi on jednostkę organizacyjną prowadzącą działalność w zakresie gromadzenia, przetwarzania, sterylizacji, przechowywania i dystrybucji tkanek i komórek. Jednostka tego rodzaju może również pobierać lub testować tkanki i komórki (A: art. 2, p. 1; Kamiński et al. 2011: 523-526). 


\section{Cele transplantacji}

Omawiana ustawa w artykule 4 enumeratywnie wylicza cztery cele, dla których mogą być pobierane komórki, tkanki i narządy ze zwłok ludzkich, nie definiując ich precyzyjnie. Pierwszy z nich to cel diagnostyczny, czyli dotyczący anatomopatologicznego rozpoznania jednostek chorobowych występujących u zmarłego pacjenta na podstawie wywiadów, badania lekarskiego, analizy objawów i wyników laboratoryjnych (Duda 2004: 24). Drugi to cel terapeutyczny, przez który należy rozumieć czynności lekarza zmierzające do ratowania życia, zdrowia lub zmniejszenia cierpieć fizycznych czy psychicznych pacjenta. Według Kazimierza Rozentala „chodzi tu o cel leczniczy zabiegu implantacji narządu lub tkanki pobranej ze zwłok w stosunku do konkretnej osoby mającej być biorcą, nie zaś o jakiś ogólny, abstrakcyjny cel służenia zdrowiu publicznemu. Tak określany cel leczniczy zabiegu lekarskiego należy rozumieć względnie szeroko. O celu leczniczym zabiegu można mówić wyłącznie wtedy, gdy osobie dokonującej zabiegu przyświecać będzie zamiar rozpoznania choroby (diagnoza), właściwego jej leczenia (terapia w znaczeniu ścisłym) lub zapobieżenie chorobie (profilaktyka) i zabieg będzie obiektywnie - tj. w świetle aktualnego stanu nauki i sztuki lekarskiej - realizacji tego zamierzenia służył" (Rozental 1992: 30). Cel leczniczy jest spełniony, gdy czynności lekarze podjęte są w zamiarze ratowania życia, zdrowia pacjenta bądź zmniejszenia jego cierpień fizycznych czy psychicznych. Cel naukowy i dydaktyczny sprowadzić można do dydaktyki prowadzonej w ramach akademickiego nauczania medycyny. Ciało dawcy ex mortuo może posłużyć do nauczania transplantologii bądź anatomii.

\section{Prawo człowieka do samostanowienia}

Ta sama ustawa, określając prawną dopuszczalność transplantacji, odrębnie reguluje pobieranie przeszczepów ze zwłok ludzkich i od żywych dawców. W obu przypadkach uzależnia jednak legalność transplantacji od poszanowania prawa dawcy do samostanowienia. Prawo to wyraża się przede wszystkim w konieczności uzyskania zgody dawcy na pobranie od niego narządu lub tkanki do przeszczepienia, bez której interwencja transplantacyjna jest nielegalna. W przypadku pobrania przeszczepu od żywego dawcy konieczne jest uzyskanie pisemnej zgody dawcy na pobranie od niego przeszczepu, która nie może być wyrażona in blanco, lecz musi dotyczyć określonego biorcy (wymóg określenia biorcy przeszczepu nie dotyczy pobrania szpiku lub innej regenerującej się komórki i tkanki). Lekarz nie ma prawa samowolnie zmieniać celu przeznaczenia narządów nieregenerujących się, na których pobranie wyraził zgodę dawca ex vivo. Jeżeli więc dawca ex vivo wyraził wolę, że przeznacza swój organ ściśle określonemu biorcy, to jego narząd nic może być przeszczepiony innemu biorcy, choćby przemawiał za tym stan wyższej konieczności (Żelichowski 2009: 146).

Nieco inaczej wygląda sprawa uzyskania zgody na przeszczep ex mortuo. Ustawa stwierdza, że „sama osoba, o której zwłoki chodzi" podejmuje decyzję pozytywną albo negatywną. Decyzja pozytywna, wyrażona przed śmiercią i dopuszczająca pobranie przeszczepów ze zwłok ludzkich, może przybrać formę tzw. zgody domniemanej. Zgodnie bowiem z art. 5 ust. 1 „pobrania komórek, tkanek lub narządów ze zwłok ludzkich w celu ich przeszczepienia można dokonać, jeżeli osoba zmarła nie wyraziła za życia sprzeciwu". Oznacza to, że przypuszczalnie za życia wyraziłaby się aprobująco o możliwości ofiarowania swoich organów potrzebującej osobie. Decyzja negatywna, zakazująca pobranie przeszczepów, powinna wynikać ze stwierdzenia podważenia domniemania zgody donatora (Tokarczyk 2000: 24). Podważenie to powinno się opierać na istnieniu jednej z form sprzeciwu na pobranie narządów wyrażonego przed śmiercią przez potencjalnego dawcę przeszczepów: wpis do Centralnego Rejestru Sprzeciwów; pisemne oświadczenie podpisane własnoręcznie; ustne oświadczenie, które zostało złożone w obecności przynajmniej dwóch 
świadków i pisemnie przez nich potwierdzone (A: art. 6, p. 1; Kubicki 2003: 56; Biesaga 2006: 9-13) ${ }^{3}$. W każdym czasie donator może wycofać swój sprzeciw w formach, o których mowa powyżej.

\section{Zgoda domniemana}

W myśl art. 5 ust. 1 polskiej ustawy transplantacyjnej „pobranie komórek, tkanek lub narządów ze zwłok ludzkich w celu ich przeszczepienia można dokonać, jeżeli osoba zmarła nie wyraziła za życia sprzeciwu”. Sformułowanie „w celu ich przeszczepienia” budzi poważne wątpliwości etyczno-prawne. Zapis ustawy wyraźnie wskazuje, że instytucja sprzeciwu ma zastosowanie jedynie w przypadku pobierania tkanek, komórek i narządów w celach leczniczych. Stanowisko takie podziela m.in. M. Żelichowski, który uważa, że „prawo do samostanowienia nie sięga poza granice życia człowieka, jakkolwiek prawo pozytywne może mu przyznać pewne uprawnienia przekraczające tę granicę, np. właśnie możność wyrażenia sprzeciwu na pobranie post mortem. Taki punkt widzenia prowadzi do wniosku, iż art. 5 ust. 1 przyznaje dawcy uprawnienie do wyrażenia sprzeciwu na pobranie organów po śmierci tylko do celu leczniczego. Nie ma on jednak uprawnienia do wyrażania ewentualnego sprzeciwu wobec pozostałych celów: diagnostycznego, naukowego i dydaktycznego" (Żelichowski 2007: 7).

3 „W przypadku małoletniego lub innej osoby, która nie ma pełnej zdolności do czynności prawnych, sprzeciw może wyrazić za ich życia przedstawiciel ustawowy, a w przypadku małoletniego powyżej lat szesnastu sprzeciw może wyrazić również on sam. Zapisy te są analogiczne do regulacji dotyczących zgody pacjenta na leczenie $\mathrm{w}$ zakresie osób małoletnich, wynikających m.in. z ustawy o zawodzie lekarza i lekarza dentysty. Podobnie sprawa sprzeciwu wygląda w stosunku do osób ubezwłasnowolnionych. Należy podkreślić, iż do skuteczności sprzeciwu wystarczy, iż jest on wyrażony przez jedną ze stron, tj. Małoletniego powyżej 16 roku życia lub jego przedstawiciela ustawowego i nie musi to być sprzeciw równoległy, wyrażony przez obie strony" (Żaba et al. 2009: 160).
Można zatem uznać, że prawo pozytywne proporcjonalnie ogranicza prawo do samostanowienia w zakresie decydowania o losie swojego ciała po śmierci i pobierania z niego materiału biologicznego. Polskie regulacje transplantacyjne przyznają osobie prawo do wyrażenia za życia sprzeciwu na pobranie z jego zwłok komórek, tkanek i narządów, nie przyznają zaś prawa do sprzeciwienia się pobraniu tych elementów w celach diagnostycznych, naukowych i dydaktycznych. Za zgodne z prawem można więc uznać pobieranie ex mortuo, jeżeli dawca nie wyraził za życia sprzeciwu na pobranie z jego zwłok komórek, tkanek i narządów lub nie złożył oświadczenia, w którym zastrzegł, że przeznacza swoje ciało wyłącznie np. do celów leczniczych i tylko dla określonych biorców. Skuteczny sprzeciw wstrzymuje jedynie pobranie narządów w celach terapeutycznych, nie ma natomiast zastosowania w przypadku pobierania tkanek dla potrzeb rozpoznania przyczyny zgonu i oceny w czasie sekcji zwłok postępowania leczniczego (A: art. 5, p. 4).

Podobnie każde pobranie komórek, tkanek i narządów wyłącznie do celów naukowych i dydaktycznych wiąże się z koniecznością uzyskania uprzedniej zgody donatora. Oznacza to, że zmarły musiałby za życia wyrazić zgodę na dysponowanie jego ciałem do celów naukowych i niewystarczający jest w tym przypadku jedynie brak sprzeciwu. Mocy wyrażenia takiej zgody (lub sprzeciwu) nie ma także rodzina zmarłego, ponieważ zwłoki nie pozostają w dyspozycji prawnej ani nie należą do masy spadkowej członków rodziny (Żaba 2009: 164). Zdaniem Nesterowicza i Śliwki dosłowne traktowanie zapisów ustawy oznacza brak możliwości prowadzenia badań naukowych w oparciu o materiał biologiczny zabezpieczony ze zwłok. Dotyczy to takich dziedzin medycyny jak patomorfologia czy medycyna sądowa, ale może mieć także znaczenie dla samej transplantologii. W celu rozwiązania swoistego impasu prawnego proponują rozszerzenie zakresu zgody domniemanej o możliwość pobierania narządów, tkanek i komórek ze zwłok 
również do celów diagnostycznych lub naukowych, jeśli dana osoba nie wyraziła za życia sprzeciwu (Nesterowicz, Śliwka 2009: 5-12). Zdaniem Biura Orzecznictwa Sądu Najwyższego pobranie komórek, tkanek i narządów dla celów naukowych czy dydaktycznych powinno być także uzależnione od wyraźnej zgody osób najbliższych zmarłego dawcy (Sąd Najwyższy 1999: 1).

\section{Zakończenie}

Ustawa z dnia 1 lipca 2005 roku o pobieraniu, przechowywaniu i przeszczepianiu komórek, tkanek i narządów już od ponad dekady stanowi podstawę legislacyjną dla ingerencji transplantacyjnych w Polsce. Wprowadzając szczegółowe ramy prawne transplantacji nie zakończyła dyskusji dotyczących przede wszystkim warunków pobierania organów do przeszczepów. Praktyka transplantacyjna objawiła słabości przyjętej w ustawie zasady zgody domniemanej, szczególnie w kontekście celów transplantacji (Breczko 2011: 374; Wróbel 1996: 99). Zasada ta, wpisująca się w prawo każdego człowieka do samostanowienia o tym, co ma się stać z jego ciałem po śmierci (Bołoz 2007: 119), w myśl polskich regulacji odniesiona została do pobierania narządów, tkanek i komórek wyłącznie do celów terapeutycznych. Należy zauważyć, że tak wąski zakres zgody domniemanej nie sprzyja wzrostowi przeprowadzanych eksplantacji narządów do celów innych niż przeszczepianie. Być może rozwiązaniem tej sytuacji mogłyby stać się nowelizacja istniejącego prawa, a szczególnie tych zapisów ustawy transplantacyjnej, które dotyczą zagadnień zgody domniemanej oraz sprzeciwu na pobranie narządów ex mortuo. Ewentualna zmiana przepisów transplantacyjnych poprzedzona powinna być debatą w środowisku prawniczym i lekarskim, a także możliwie szerokim dialogiem ze społeczeństwem i odpowiednią akcją, wspartą dodatkowo przez autorytety moralne i mającą na celu zwiększenie świadomości społecznej podstawowych zagadnień związanych z przeszczepianiem narządów.

\section{Bibliografia:}

Biesaga T., 2006, Wobec zgody domniemanej i zawłaszczania zwłok do transplantacji, Medycyna Praktyczna Ginekologia i Położnictwo, Vol. 2, 9-13. Bołoz W., 2007, Bioetyka a prawa człowieka, Warszawa.

Bogusławski S. (red.), 1987, Mała encyklopedia medycyny, Wyd. PWN, Warszawa.

Breczko A., 2011, Podmiotowość prawna człowieka w warunkach postępu biotechnomedycznego, Wyd. Temida 2, Białystok.

Duda J., 2004, Transplantacja w prawie polskim. Aspekty karnoprawne, Wyd. Zakamycze, Kraków.

Duda J., 2011, Cywilnoprawna problematyka transplantacji medycznej, Wyd. Wolters Kluwer Polska, Warszawa.

Gomułka W.S., Rewerski W., 2ooo, Encyklopedia zdrowia, Wyd. PWN, tom II, Warszawa.

Guzik-Makaruk E.M., 2008, Transplantacja organów, tkanek $i$ komórek w ujęciu prawnym i kryminologicznym, Wyd. Temida 2, Białystok.

Kamiński A., Uhrynowska-Tyszkiewicz I., Wanyura H., 2011, Wymogi prawne dotyczace stosowania ludzkich biostatycznych przeszczepów tkankowych w chirurgii czaszkowo-szczękowo-twarzowej i stomatologiczne, Journal of Stomatology, Vol. 64, 521-534.

Koreywo M., 1969, Medycyna dzisiejsza, Wyd. PZWL, Warszawa.

Kowalewska B., Truszkowska E., Klimaszewska K., 2013, Przeszczepianie narząów w opinii społeczeństwa na przykładzie studentów - podstawy teoretyczne, w: Krajewskiej-Kułak E., Łukaszuk C.R., Lewko J., Kułak W. (red.), „W drodze do brzegu życia”, tom XI, Wyd. Duchno, Białystok, I33-I47.

Krąpiec M.A., 1997, Natura ludzkiej wolności, Człowiek w Kulturze Vol. 9, 21-31.

Kubicki L. (red.), 2003, Prawo Medyczne, Wyd. Urban \& Partner, Wrocław.

Nesterowicz M., Śliwka K., 2009, Pobieranie ze zwłok komórek, tkanek i narządów do celów naukowych problem prawny $i$ medyczny, Prawo i Medycyna, Vol. 4, 5-12.

Ptaszek G., Stołecka B., Mroczkowska R., 2016, Transplantacja - nadzieja na nowe życie, w: Krajewskiej-Kułak E., Łukaszuk C.R., Lewko J., Kułak W. (red.), „W drodze do brzegu życia”, tom XIV, Wyd. Duchno, Białystok, IO2-II2. 
Rozental K., 1992, Nowe uregulowania ustawowe dotyczace transplantologii, Przegląd Sądowy Vol. 9.

Szmidt J., 2003, Podstawy chirurgii - podręcznik dla lekarzy specjalizujacych się w chirurgii ogólnej, Wyd. Medycyna Praktyczna, tom 1, Kraków.

Tokarczyk R., 2000, Zarys regulacji transplantacji organów ludzkich, Ruch Prawniczy, Ekonomiczny i Socjologiczny, Vol. 62, z. 1, 15-31.

Wałaszewski J., Stryjenka-Rowińska D., 2004, Dawcy narzadów unaczynionych, w: Rowiński W., Wałaszewski J., Pączek I. (red.), Transplantologia kliniczna, Wyd. PZWL, Warszawa, 35-38; 48-49. Wiśniewska-Śliwińska H., 2014, Ocena potrzeb edukacyjnych na rzecz świadomej transplantacji i donacji narząów, w: Krajewskiej-Kułak E., Łukaszuk C.R., Lewko J., Kułak W. (red.), „W drodze do brzegu życia”, tom XII, Wyd. Duchno, Białystok, I84-196.

Wolf P., Boudjema K., Ellero B., Cinqualbre J., 1993, Transplantacja narzadów. Kompendium, tłum. S. Michowicz, J. Michowicz, D. Patrzałek, Wyd. Volumed, Wrocław.

Wróbel J., 1996, Zgoda domniemana w Polskiej ustawie transplantacyjnej. Watpliwości i obawy natury etycznej, w: Marcol A. (red.), „Etyczne aspekty transplantacji narządów. Materiały z sympozjum z Kamienia Śląskiego 15-16.04.1996", wyd. Wydziału Teologicznego Uniwersytetu Opolskiego, Opole.

Youngson R.M., 1997, Stownik encyklopedyczny medycyna, Wyd. RTW, Collins, 404.

Żaba Cz., Świderski P., Żaba Z., Grześkowiak M., 2009, Prawno-medyczne aspekty pobierania narzadów ze zwłok, Nowiny Lekarskie, Vol. 78, z. 2, 159-164.

Żelichowski M., 2007, Pobranie komórek, tkanek i narzadów: zgoda jest reguta sprzeciw wyjatkiem, Rzeczypospolita, 25.09.2007, 7.

Żelichowski M., 2009, Aspekty prawne transplantacji, Medycyna Praktyczna, Vol. 1, 145-147.

A: Ustawa z dnia 1 lipca 2005 r. o pobieraniu, przechowywaniu i przeszczepianiu komórek, tkanek i narządów (Dz.U.2005.169.1411)

B: Rozporządzenie Ministra Zdrowia z dnia 25 kwietnia 2006 r. w sprawie wymagań dla kandydata na dawcę komórek, tkanek lub narządu (Dz.U.2006.79.556).

C: Ustawa z dnia 5 grudnia 1996 r. o zawodach lekarza i lekarza dentysty (Dz.U.2005.226.1943).

\section{A presumed consent in a transplantology context}

\section{Summary}

The author, in his paper, pays close attention to a presumed consent and wider a right to self-determination, which is meant as an act of decision in a transplantology context. Polish legislation of transplantation from 2005 in article 4 lists four reasons for transplantation of organs: post-mortem autopsy, therapeutic, academic and didactic. Simultaneously, article 5 states that transplantation of organs for a therapeutic reason is possible when the deceased person distinctly hadn't disagreed for such an action. If there are no clear objections against transplantation, and the deceased person does not carry a note of which could suggest otherwise, the physician can legally assume that the person had agreed for an organ sampling (from a presumed consent). A phrase "for a therapeutic reason" evidently points out that donor's disagreement is only valid in a face of organ, tissue and cell harvest for a medicinal cause. However, organs sampling: post-mortem autopsy, which is both academic and didactic as, does not fall under the same regulations, as it will be conducted regardless of presence or lack of permit of family or the will statement of the deceased one. On the other side, every organ sampling for academic and didactic reasons, requires a separate declaration from a donor as lack of their disagreement is not sufficient in this case. To resolve this forensic-legal deadlock, it is suggested to extend a presumed consent of organs sampling.

\section{Key words}

a presumed consent, transplantation targets, transplantology, the right of self-determination, disagreement. 